\title{
Bovine Papillomatosis and its Treatment under Farm Condition
}

\author{
S.N. Archana*, A. Prasad, Justin Davis and T.X. Seena \\ Cattle Breeding Farm, Thumburmuzhy, India \\ *Corresponding author
}

\section{A B S T R A C T}

\begin{tabular}{l} 
Ke y w o r d s \\
Bovine \\
papilomatosis, \\
Thuja, \\
Anthiomaline, \\
Autogenous vaccine \\
\hline Article Info \\
\hline $\begin{array}{l}\text { Accepted: } \\
\text { 20 March } 2019 \\
\text { Available Online: } \\
\text { 10 April } 2019\end{array}$ \\
\hline
\end{tabular}

Keywords

Bovine

papilomatosis,

Thuja,

Anthiomaline,

Autogenous vaccine

\section{Introduction}

Cutaneous papilomatosis is also known as warts, which is an epithelial cell over growth, infectious in nature and appears approximately eight weeks after exposure to the infectious virus. It is highly contagious disease that can be easily spread from one animal to other by close contact. The indirect transmission of these viruses is possible by contaminated feeders, waters, halters and even pen walls. Warts are caused by a highly contagious virus known as papillomas, these are small, cauliflower-shaped growths occur on very young animals. The warts are characterized by solid outgrowth of the epidermis with cauliflower like appearance.
These are most commonly seen on the nose, chin, lips, neck, shoulder and brisket region of the body. The presence of warts on the different body parts diminishes the value and aesthetic quality of the animal. Once an animal acquires the disease, it usually develops immunity within three weeks to four weeks after the initial infection. Warts are commonly seen in all animal species (Radostits et al., 2007), and are highly species-specific (Borzacchiello and Roperto 2008). There are four major types of warts i.e. squat, pedunculated, flat and tags. Though warts are little harm and disappear spontaneously over long time, but recurrence of papilloma's can be noticed under improper hygiene and care. Sharma et al., (2005) 
reported that occurrence of papillomas were observed in winter season (37.78 per cent) followed by autumn (33.33 per cent), summer (20.00 per cent) and spring (8.89 per cent) respectively. Surgery and vaccination, or a combination of both is the most common forms of treatment and prevention. There are no exact drug regimens for warts to prevent its reoccurrence. The homeopathic medicine, autogenous vaccine, autoheamotherapy and anthiomaline can be used for the treatment. In the present study, the comparison between the effect of anthiomaline, autogenous vaccine and homeopathic medicine thuja is studied.

\section{Materials and Methods}

In the present study eight heifers having warts on different part of body were selected. All the animals were isolated and kept in a different pen for complete observation. These animals were differentiated into four groups each having two animals with different treatment i.e. homeopathic thuja (group one), anthiomaline (group two) and autogenous vaccine (group three) treatment. Two animals were separated and marked as control (group four).

\section{Preparation of Autogenous Vaccine}

The samples from the older growths of affected animals were resected under aseptic conditions after injecting xylazine $0.7 \mathrm{ml}$ intramuscular as shown in figure 1. The resected wart (Fig. 2) sample was suspended in normal saline $(30 \mathrm{ml} / \mathrm{g}$ of tissue) and minced properly using mortar and pestle.

Further, the minced sample were filtered through muslin cloth and treated with formalin $(0.4 \mathrm{ml}$ per $100 \mathrm{ml}$ of filtrate), to inactivate the virus and kept overnight. An antibiotic i.e. Strepto-Pencillin $2 \mathrm{mg} / \mathrm{ml}$ was also added in the filtrate and transferred into vials and kept at 0 to $4^{0} \mathrm{C}$ until use.

\section{Treatment}

Thuja is a plant derivative obtained from Thuja occidentalis which is used for homeopathic preparation available in market with a brand name of Thuja-30. In the present study, two animals in group one were treated with oral administration of 10 drops of thuja extract twice a day and topical application of thuja ointment at the site of wart for four weeks (Kavithaa et al., 2014). The animals in the group two were treated with $15 \mathrm{ml}$ of Anthiomaline which was administered by deep intramuscular route at 48 hours interval for four weeks, each $\mathrm{ml}$ of anthiomaline contains $60 \mathrm{mg}$ of Lithium Antimony thiomalate. The animals in third group were treated using prepared autogenous vaccine administered at a dose rate of $5 \mathrm{ml}$ subcutaneously and revaccinated at 7 day intervals for four weeks (Sreeparvathy et al., 2011). Each animal in different treatment were observed up to four week until termination of treatment.

\section{Results and Discussion}

The current study revealed that the warts are commonly occurring in the heifers and this can be spread from one animal to other by contact. The papillomatosis is occurring due to several factors including inheritance, hormonal disorder and suppressed immune system (Campo et al., 1994). Immunity of an animal plays a major role in acquiring the infection (Inayat et al., 1999). Treatment with Thuja occidentalis (thuja-30, a homeopathic medicine) at the rate of 10 drops twice a day along with application of Thuja ointment on the affected area for a span of four weeks was found to be 100 per cent effective in complete sloughing of wart and development of normal tissue as shown in figure 3. Shakoor et al. (2012) reported 100 per cent recovery of wart after continuous oral administration of Thuja for three weeks in dairy cattle. 
Fig.1

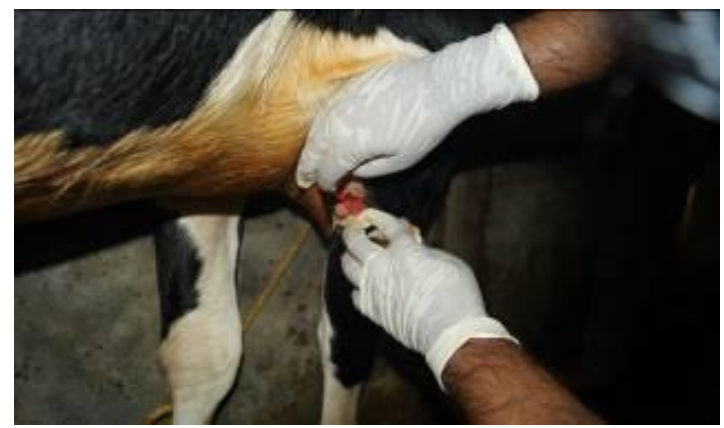

Fig. 2

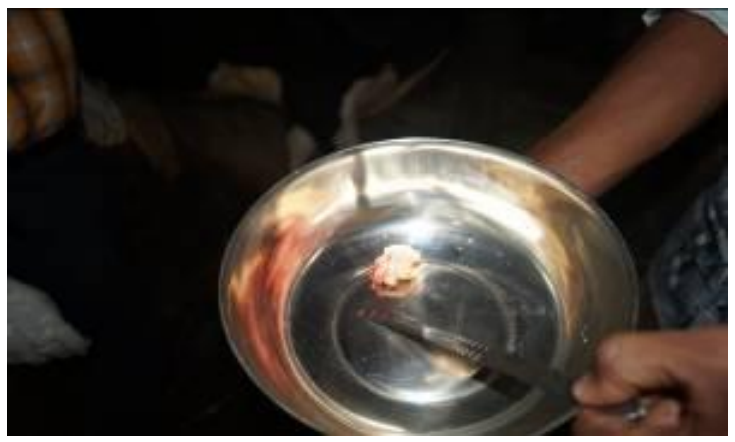

Fig.3 Animal treated with Thuja (Homeopathic medicine)

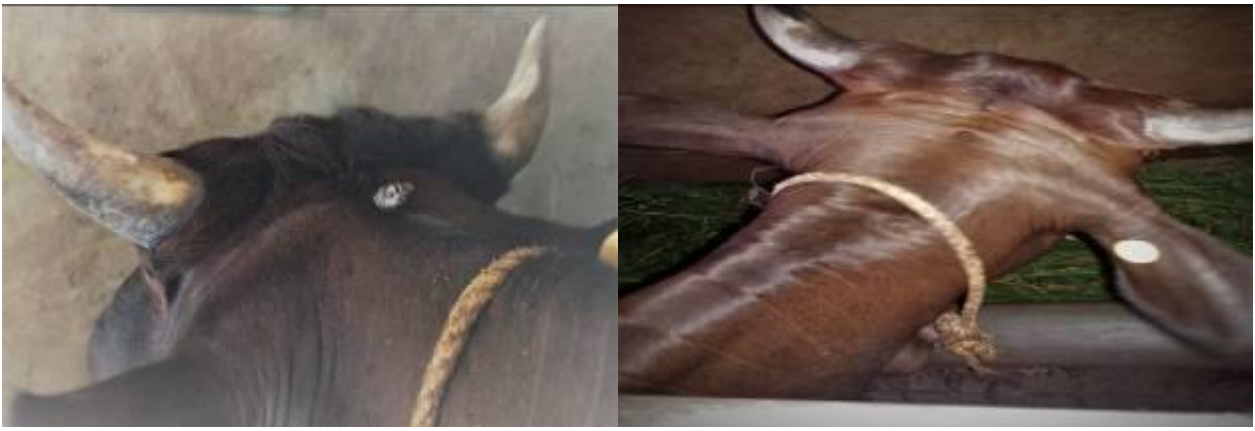

Fig.3 (a) Before treatment

Fig.3 (b) After treatment

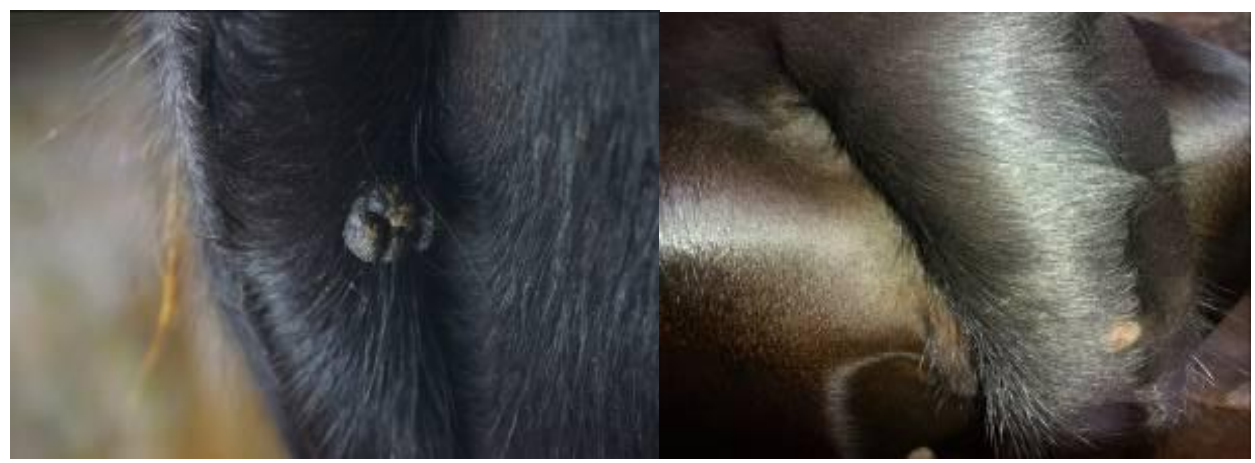

Fig.3 (c) Before treatment

Fig.3 (d) After treatment 
Fig.4 Animal treated with Anthiomaline

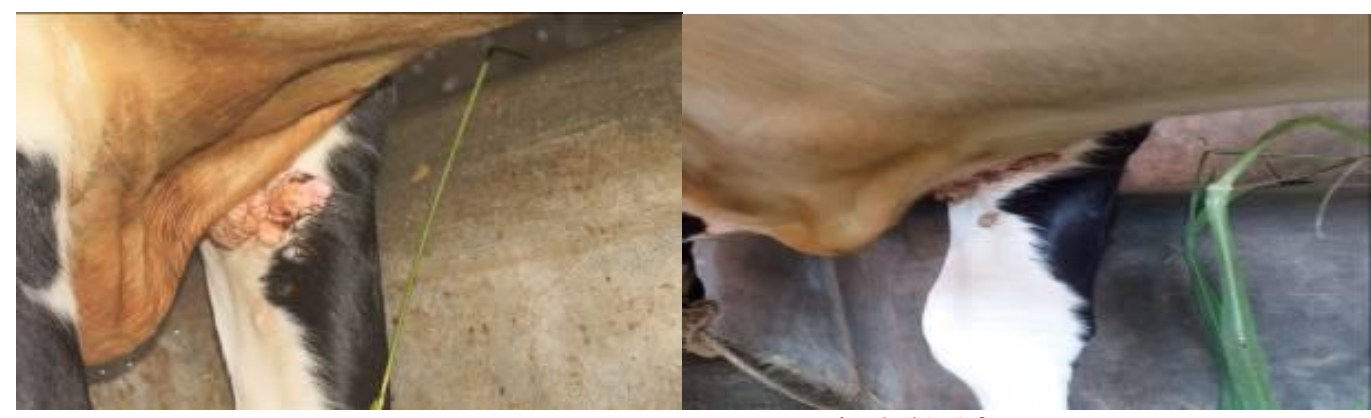

Fig.4 (a) Before treatment

Fig.4 (b) After treatment

The major drawback of homeopathic medicine is that it takes more time to exert its effect in animal but results are observed after treating continuously for one month. Administration of Anthiomaline $15 \mathrm{ml}$ by deep intramuscular route at 48 hours interval for four weeks revealed 75 per cent reduction in the papillomatous growth as shown in figure 4.

A study conducted in Erode by Kavitha et al. (2014) shows that treatment of wart affected animal with anthiomaline recovered 81 per cent of infection. In the present study, administration of prepared autogenous vaccine showed zero efficiency in curing the condition. A study conducted by Pence (2005) also showed that autogenous vaccine was ineffective in regression of warts. In contrast to the present study, Ranjan et al. (2013) reported that autogenous vaccine was found to be effective in treating bovine papillomatosis. Commercial vaccines are more effective if they contain the specific strain that is involved in the infection. Autogenous vaccines are usually made by veterinarian and involve removing the wart to produce a specific virus sero-type vaccine. Success of vaccination is depended on individual immunity and its response to the vaccination.

In conclusion, the present study revealed that treatment of bovine papillomatosis using Thuja (homeopathic medicine) was found to be most effective therapy followed by anthiomaline. Zero cure rates were noticed in the wart after four weeks of treatment using prepared autogenous vaccine.

\section{References}

Borzacchiello, G. and Roperto, F. (2008). Bovine papillomaviruses, papillomas and cancer in cattle. Vet. Res. 39: 1

Campo, M.S., Jarrett, W.F.H., O'neil, W. and Barron, R.J. 1994. Latent papilloma virus infection in cattle. Res. Vet. Sci. 56: 151-157.

Inayat, A., Muhammed, G., Asi, M.N., Saqib, M. and Athar, M. 1999. Use of autogenous vaccine for the treatment of generalized papillomatosis in cattle. Pakist. Vet. J. 19: 102-103

Kavithaa, N.V., Rajkumar, N.V. and Jiji, R.S. 2014. Papillomatosis in jersey cows and its different medical treatment. Int. J. Sci. Environ. Technol. 3: 692-694.

Pence, M.E. 2005. Cattle warts-and show cattle.

Radostits, O.M. and Gay, C.C. 2007. Veterinary Medicine: A Textbook of the Diseases of Cattle, Horses, Sheep, Pigs and Goats. (10th edn). Elsevier Health Sciences, Philadelphia, PA, USA, 337-352p.

Ranjan, R., Ghumman, S.P.S., Bhatt, G.R. and Singh, R.S. 2013. Efficacy of autogenous vaccine and auto- 
hemotherapy in bovine cutaneous papillomatosis. Intas Polivet, 14: 411415.

Sharma, S., Singh, K.B., B.K., Bansal and D.K. Sharma. 2005. Buffalo Bull. 24: 12

Shakoor, A., Muhammad, S.A., Kashif, M., Rehman, Z.U., Hussain, A. and Hameed, M.R. 2012. Effects of Thuja occidentalis as an alternative remedy in the treatment of Papillomatosis in Cattle. Vet. Wld. 5: 118-120.

Sreeparvathy, M., Harish, C. and Anuraj, K.S. 2011. Autogenous vaccination as a treatment method for bovine papillomatosis. J. Livestock Sci, 2: 3840.

\section{How to cite this article:}

Archana, S.N., A. Prasad, Justin Davis and Seena, T.X. 2019. Bovine Papillomatosis and its Treatment under Farm Condition. Int.J.Curr.Microbiol.App.Sci. 8(04): 2880-2884. doi: https://doi.org/10.20546/ijcmas.2019.804.336 